\title{
Ionization Constants and Reactivity of Isomers of Eugenol
}

\author{
G. M. Brauer, H. Argentar, and G. Durany
}

(July 15, 1964)

\begin{abstract}
To determine the scope of the reaction of zinc oxide with isomers of eugenol, the effect of changes in the position of the substituents in the benzene ring on the ionization constants and reactivity of these isomers has been studied.

The ionization constants of eugenol isomers as well as those of newly synthesized allyland propenylbenzoic acids were determined by spectrophotometric and potentiometric techniques. The influence of inductive, resonance and steric effects of the substituents on the ionization constants has been discussed and the substituent constant for the Hammett equation $p K_{0}-p K=\sigma \rho$ has been calculated. For the 4- and 5-substituted allyl and propenyl derivatives, the Hammett equation is valid.

Vicinal trisubstituted isomers do not harden readily with zinc oxide due to the steric hindrance of the side chain. The unsymmetrically trisubstituted derivatives react rapidly in the presence of zinc acetate. Besides the steric effects of ths substituent groups the rate of the chelation reaction is to a lesser degree dependent on the ionization constants as indicated by the shorter setting time of chavibetol-zinc oxide slurries compared to those containing eugenol.
\end{abstract}

\section{Introduction}

Mixtures of zinc oxide and 4-allyl-2-methoxyphenol (eugenol) harden to form a product that consists of zine oxide embedded in a matrix of zinc eugenolate chelate [1]. ${ }^{1}$ To determine the scope of this reaction it appeared of interest to study how changes of the position of substituent groups in eugenol affect the behavior of the isomers as evidenced by their ionization constants, absorption spectra, hydrogen bonding and reactivity with zinc oxide. The absorption spectra studies will be discussed in a subsequent paper.

\section{Experimental Procedures and Results}

\subsection{Materials}

The eugenol isomers that are commercially available-4-allyl-2-methoxyphenol, 2-methoxy - 5-propenylphenol (isochavibetol), and trans-2-methoxy-4propenylphenol (trans-isoeugenol)-were redistilled or recrystalized; the final boiling or melting points agreed with those given in the literature.

The synthesis of 3-allyl-2-methoxyphenol, 3-allyl5 -methoxyphenol (chavibetol), 6-allyl-2-methoxyphenol (o-eugenol), and 2-methoxy-4-propenylphenol has been described previously [2]. p-Allylphenol (chavicol) and p-propenylphenol (anol) were synthesized from $p$-allylanisole (estragole) and $p$-propenylanisole (anethole) by demethylation with methyl magnesium iodide. The procedures were similar to those employed by Schöpf and coworkers for the demethylation of 4-allyl-1,2-dimethoxybenzene (methyleugenol) [3]. 2-Methoxy-6-propenylphenol (o-isoeugenol) was prepared by the method of Pal'gi [4]. $p$-Allylbenzoic and p-pro-

1 Figures in brackets indicate the literature references at the end of this paper. penylbenzoic acids were synthesized from $p$-dibromobenzene through a series of reactions described by Quelet [5,6].

The $m$-allylbenzoic acid was synthesized by modifying the procedure given by Quelet for the paraisomer $[5,6]$. To $5.8 \mathrm{~g}(0.24 \mathrm{gram}$ atom $)$ of magnesium and a few crystals of iodine, $50 \mathrm{ml}$ of ether was added and the solution was refluxed until the purple color changed to pale green (approximately $30 \mathrm{~min})$. Then $50 \mathrm{~g}(0.21 \mathrm{~mole})$ of $m$-dibromobenzene in $50 \mathrm{ml}$ of ether was added and the solution refluxed for $2 \mathrm{hr}$ when most of the magnesium had reacted. Allyl bromide (20 ml, 0.24 mole) dissolved in $25 \mathrm{ml}$ of ether was added dropwise with cooling to keep the temperature of the reaction mixture between 5 and $15^{\circ} \mathrm{C}$. After refluxing for $18 \mathrm{hr}$, the Grignard reagent was decomposed with saturated ammonium chloride adjusted to $p \mathrm{H} 8$ with $\mathrm{NH}_{4} \mathrm{OH}$, the ether was evaporated, and the residue was steam distilled. Sodium chloride was added to the distillate, the product was separated from the water and dried over calcium chloride. The $m$ bromoallylbenzene containing traces of dibromobenzene distilled at $76-78{ }^{\circ} \mathrm{C} / 6 \mathrm{~mm}, n_{\mathrm{D}}{ }^{30}=1.549$. Yield: $22 \mathrm{~g}(47 \%)$.

The acid was prepared from $m$-bromoallylbenzene as follows: To $0.92 \mathrm{~g}$ magnesium (0.038 gram atom) in $25 \mathrm{ml}$ of ether a few crystals of iodine were added and the mixture refluxed until the iodine color disappeared. After addition of $7.0 \mathrm{~g}$ (0.0355 mole) $m$-bromoallylbenzene dissolved in $25 \mathrm{ml}$ of ether, the mixture was refluxed for $24 \mathrm{hr}$, cooled to $5{ }^{\circ} \mathrm{C}$, and dry ice was added over a $4-\mathrm{hr}$ period. The mixture was poured onto crushed ice, $100 \mathrm{ml}$ of 10 percent $\mathrm{HCl}$ was added, and the ethec layer was separated and extracted with dilute sodium bicarbonate. The extract was acidified and the precipitate extracted with ether. The yellow solid obtained on evaporation of the ether was recrystallized from 
water and dilute ethanol yielding $0.9 \mathrm{~g}(16 \%)$ of $m$-allylbenzoic acid, $m p$ 61-62 ${ }^{\circ} \mathrm{C}$.

Anal: Calcd. for $\mathrm{C}_{10} \mathrm{H}_{10} \mathrm{O}_{2}$ : C, $74.05 ; \mathrm{H}, 6.2$; neut. equiv. 162.2. Found: $\mathrm{C}, 74.2 ; \mathrm{H}, 6.3$; neut. equiv. 161.1.

By modifying the synthesis given for the para isomer $[5,6], m$-propenylbenzoic acid was obtained through the following reaction steps:

The $m$-bromophenylmagnesium bromide was prepared as described above. The mixture was cooled to $5{ }^{\circ} \mathrm{C}$ and $14 \mathrm{~g}(0.24$ mole) of propionaldehyde in 50 $\mathrm{ml}$ of ether was added dropwise with stirring to keep the temperature of the highly exothermic reaction between 5 and $12{ }^{\circ} \mathrm{C}$. The mixture was kept overnight at room temperature and was decomposed with crushed ice. Then $100 \mathrm{ml}$ of 10 percent $\mathrm{HCl}$ was added. The water layer was separated and extracted with ether. The ether extracts and original ether layer were combined, dried with anhydrous sodium sulfate, and the ether was evaporated off. On distillation at $123-128{ }^{\circ} \mathrm{C} / 6 \mathrm{~mm}$ there was obtained $20 \mathrm{~g}$ (44\% yield based on $m$-dibromobenzene) 1 -( $m$-bromophenyl $)-1$-propanol, $n_{D}^{23}=1.5580$.

Anal: Calcd. for $\mathrm{C}_{9} \mathrm{H}_{11} \mathrm{OBr}$ : C, 50.3; H, 5.2. Found: C, $50.9 ; \mathrm{H}, 5.1$.

On dehydration of $20.7 \mathrm{~g}$ (0.096 mole) $1-(\mathrm{m}$ bromophenyl)-1-propanol by refluxing for $19 \mathrm{hr}$ with $9 \mathrm{~g}(0.063$ mole $) \mathrm{P}_{2} \mathrm{O}_{5}$ in $150 \mathrm{ml}$ of benzene (dried over sodium) there was obtained $6.83 \mathrm{~g}(36 \%)$ 1 -( $m$-bromophenyl)propene, bp $92-93{ }^{\circ} \mathrm{C} / 6 \mathrm{~mm}$, $n_{D}^{28}=1.5855$.

Anal: Calcd. for $\mathrm{C}_{9} \mathrm{H}_{9} \mathrm{Br}$ : C, 54.85; H, 4.6. Found: C, $54.7 ; \mathrm{H}, 4.4$.

The 1 -( $m$-bromophenyl)propene $\quad(3.0 \mathrm{~g}, \quad 0.015$ mole) was converted to the acid by refluxing it with $0.39 \mathrm{~g}$ (0.016 gram atom) magnesium and $25 \mathrm{ml}$ of ether for 3 days and subsequent addition of dry ice. The $m$-propenylbenzoic acid was recovered from the reaction mixture as described in the preparation of $m$-allylbenzoic acid. After recrystallation from acetic acid-water and ethanol-water the colorless needles melted at $104.5-105.5{ }^{\circ} \mathrm{C}$. Yield: $0.5 \mathrm{~g}$ $(21 \%)$.

Anal: Calcd, for $\mathrm{C}_{10} \mathrm{H}_{10} \mathrm{O}_{2}$ : C, $74.05 ; \mathrm{H}, 6.2$; neut. equiv. 162.2. Found: C, 74.0; H, 6.3 ; neut. equiv. 163.1 .

\subsection{Ionization Constants}

The thermodynamic ionization constants of eugenol isomers and related phenols were determined spectrophotometrically according to the procedure of Robinson and Big's [7]. This method depends upon the fact that the ultraviolet absorption spectrum of a weak acid is often markedly dependent on $p \mathrm{H}$; that is, in an alkaline solution one obtains the spectrum of the negatively charged anion of the acid whereas in an acidified solution one measures the spectrum of the uncharged molecule of the weak acid. Thus a range of wavelengths can be found in which the anion is highly absorbent and the uncharged molecule shows little if any absorption. All measurements were made with a Beckman DU spectrophotometer thermostated at $25.0 \pm 0.1{ }^{\circ} \mathrm{C}$.
The optical density at a specific wavelength was studied in acidic $(0.1 N \mathrm{HCl})$ and alkaline $(0.1 N$ $\mathrm{NaOH})$ media as well as solutions that had been buffered. Buffers used were equimolar mixtures of $0.25 M$ or $0.01 M$ sodium carbonate and sodium bicarbonate $(p \mathrm{H}=10.020$ and $10.112[8,9]), 0.1 M$ and $0.01939 M$ solutions containing sodium acid succinate and sodium chloride $(p \mathrm{H}=4.802$ and 4.853 [10] and $0.06 M$ sodium acetate and $0.14 M$ acetic acid $(p \mathrm{H}=3.875[11])$ at $25{ }^{\circ} \mathrm{C}$. These buffers were chosen since the $p \mathrm{H}$ of the resulting solutions appeared to be in the neighborhood of the expected $p K$ values of the acids.

The negative logarithm of the thermodynamic ionization constant is given by:

$$
p K=p \mathrm{H}-\log \frac{\alpha}{1-\alpha}-\log \gamma_{A^{-}} .
$$

The degree of ionization can be calculated from the optical density $D$ of the buffered, acidic, and basic solutions.

$$
\alpha=\left(D_{\text {buffer }}-D_{\text {acld }}\right) /\left(D_{\text {base }}-D_{\text {acld }}\right) .
$$

The values of $\gamma_{A^{-}}$, the activity coefficient of the anion, were obtained from the equation

$$
-\log \gamma_{A^{-}}=\left[0.5115 I^{1 / 2} /\left(1+I^{1 / 2}\right)\right]-0.2 I,
$$

where $I=$ ionic strength [12]. The values of $-\log \gamma_{A}-$ were 0.102 and 0.077 for the $0.25 M$ and $0.01 M$ carbonate and 0.217 and 0.0418 for the $0.100 M$ and $0.01939 M$ sodium acid succinate-sodium chloride buffer solutions.

The concentration and wavelengths that would be most favorable for the determination of the ionization constant were obtained by scanning the absorption curve of the acidic and basic solution of each phenol in the 270 to $330 \mathrm{~m} \mu$ region and of the acids in the 230 to $330 \mathrm{~m} \mu$ region. The concentrations employed varied from $7 \times 10^{-5}$ to $3.5 \times 10^{-4} M$.

The propenylbenzoic acids were insoluble in $0.1 N \mathrm{HCl}$ and thus could not be determined by the spectrophotometric method. The apparent and thermodynamic $p K$ values of the propenyl- and allyl-benzoic acids were therefore determined potentiometrically at $25.0 \pm 0.1{ }^{\circ} \mathrm{C}$. A $40 \mathrm{ml} \mathrm{1:1}$ (by volume) abs. ethanol-water solution of the acid of 2.75 to $5.50 \times 10^{-3}$ molar concentration was titrated in a nitrogen atmosphere with carbonate free (approximately $0.025 N$ ) 50 percent ethanolic sodium hydroxide employing an automatic constant rate microburette (Sargent, Model C). The change in $p \mathrm{H}$ was followed using a Radiometer $p \mathrm{H}$ meter (Model 22) with scale expander which was standardized each day against aqueous $0.05 \mathrm{M}$ potassium acid phthalate $(p \mathrm{H}=4.010)$ and Beckman concentrated buffer solution diluted 24 to $1(p \mathrm{H}=7.000)$. The $p \mathrm{H}$ was measured in the buffer region where the degree of ionization is between 25 and 75 percent and also in the vicinity of the end point. The precise end point was obtained by plotting $\Delta p \mathrm{H} / \Delta \mathrm{ml}$ versus 
$\mathrm{ml}$ of $\mathrm{NaOH}$ added and taking as the end point the number of $\mathrm{ml}$ of $\mathrm{NaOH}$ at which $\Delta p \mathrm{H} / \Delta \mathrm{ml}$ is a maximum. The thermodynamic $p K$ values were calculated using the following equation:

$$
p K=p \mathrm{H}+\log \frac{C-\left[\mathrm{Na}^{+}\right]-\left[\mathrm{H}^{+}\right]}{\left[\mathrm{Na}^{+}\right]+\left[\mathrm{H}^{+}\right]}+\frac{A \sqrt{\left[\mathrm{Na}^{+}\right]+\left[\mathrm{H}^{+}\right]}}{1+B \sqrt{\left[\mathrm{Na}^{+}\right]+\left[\mathrm{H}^{+}\right]}}
$$

where

$\left[\mathrm{Na}^{+}\right]=$concentration of the sodium ion

$C=[\mathrm{HA}]+\left[\mathrm{A}^{-}\right]=$total concentration of all acid species

$[\mathrm{HA}]=$ concentration of the undissociated acid $\left[A^{-}\right]=$concentration of the anion of the acid.

The constants $A$ and $B$ depend on the solvent composition and were calculated from the expression given by Bates [13].

$A=1.825 \cdot 10^{6}(\epsilon T)^{-3 / 2}$

$B=1.5(78.3 / \epsilon)^{1 / 2}$ whera

$T=$ absolute temperature

and

$\epsilon=$ dielectric constant of the solvent which was obtained by interpolation from the values given by Ảkerlöf [14].

A Royal computer was used to calculate the $p K$ values. The standard deviation was about 0.004 $p K$ units for one titration and the standard deviation between different runs was within $0.02 p K$ units.

The degree of ionization and the thermodynamic $p K$ values obtained from the optical density measurements are given in table 1 . The $p K$ values are considered to be accurate within $\pm 0.02 p K$ units except for $p$-propenylphenol and $m$-allylbenzoic acid since the latter compounds were not stable in the buffered or basic solutions. The $p K$ values of the allyl and propenyl substituted guaiacols increase in the following order: 3 -substituted $<5$-substituted $<4$-substituted $<6$-substituted guaiacol.

TABLE 1. Thermodynamic ionization constants of allyl-and propenyl substituted phenols and benzoic acids Solvent: $\mathrm{H}_{2} \mathrm{O}$ Temperature: $25.0 \pm 0.1^{\circ} \mathrm{C}$

\begin{tabular}{|c|c|c|c|c|c|c|}
\hline Compound & $\begin{array}{l}\text { Concen- } \\
\text { tration }\end{array}$ & $\begin{array}{l}\text { Wave } \\
\text { length }\end{array}$ & $\begin{array}{c}\text { Normality } \\
\text { of } \mathrm{Na}_{2} \mathrm{CO}_{3-} \\
\mathrm{NaHCO}_{3} \\
\text { buffer }\end{array}$ & $\alpha$ & $p K$ & Avg. $p K$ \\
\hline Phenol & $10^{-4} M$ & $m_{\mu}$ & & & & $10.00[8]$ \\
\hline $\begin{array}{l}p \text {-Allylphenol } \\
\text { (Chavicol) }\end{array}$ & $\begin{array}{l}3.00 \\
3.00\end{array}$ & $\begin{array}{l}300 \\
300\end{array}$ & $\begin{array}{l}0.01 \\
.025\end{array}$ & $\begin{array}{r}0.462 \\
.452\end{array}$ & $\begin{array}{l}10.26 \\
10.21\end{array}$ & 10. 23 \\
\hline 3-Allyl-2-methoxyphenol ...... & $\begin{array}{l}3.00 \\
3.00 \\
3.00 \\
3.00\end{array}$ & $\begin{array}{l}290 \\
290 \\
300 \\
300\end{array}$ & $\begin{array}{l}.01 \\
.025 \\
.01 \\
.025\end{array}$ & $\begin{array}{l}.660 \\
.617 \\
.653 \\
.598\end{array}$ & $\begin{array}{l}9.90 \\
9.92 \\
9.91 \\
9.95\end{array}$ & 9.92 \\
\hline $\begin{array}{l}\text { 4-Allyl-2-methoxy phenol ....... } \\
\text { (Eugenol) }\end{array}$ & $\begin{array}{l}2.00 \\
2.00\end{array}$ & $\begin{array}{l}300 \\
300\end{array}$ & $\begin{array}{l}.01 \\
.025\end{array}$ & $\begin{array}{l}.514 \\
.458\end{array}$ & $\begin{array}{l}10.17 \\
10.20\end{array}$ & 10.19 \\
\hline $\begin{array}{l}\text { 5-Allyl-2-methoxyphenol } \ldots . . . .- \\
\text { (Chavibetol) }\end{array}$ & $\begin{array}{l}3.00 \\
3.00\end{array}$ & $\begin{array}{l}300 \\
300\end{array}$ & $\begin{array}{l}.01 \\
.025\end{array}$ & $\begin{array}{l}.640 \\
.593\end{array}$ & $\begin{array}{l}10.01 \\
10.03\end{array}$ & 10.02 \\
\hline $\begin{array}{l}\text { 6-Allyl-2-methoxyphenol } \ldots . . .- \\
\text { (o-Eugenol) }\end{array}$ & $\begin{array}{l}0.70 \\
3.50 \\
3.50\end{array}$ & $\begin{array}{l}300 \\
300 \\
300\end{array}$ & $\begin{array}{l}.025 \\
.01 \\
.025\end{array}$ & $\begin{array}{l}.363 \\
.374 \\
.361\end{array}$ & $\begin{array}{l}10.37 \\
10.41 \\
10.37\end{array}$ & 10.38 \\
\hline $\begin{array}{l}p \text {-Propenylphenol } \\
\text { (Anol) }\end{array}$ & $\begin{array}{l}3.00 \\
3.00\end{array}$ & $\begin{array}{l}320 \\
320\end{array}$ & $\begin{array}{l}.01 \\
.025\end{array}$ & $\begin{array}{l}\text { a. } 438 \\
\text { a. } 335\end{array}$ & $\begin{array}{l}\text { a } 9.8 \\
\text { a } 9.8\end{array}$ & $\begin{array}{l}\text { a } \sim 9.8 \\
\text { с } 9.824\end{array}$ \\
\hline $\begin{array}{l}\text { 2-Methoxy-4-propenylphenol_.-- } \\
\text { (Isoeugenol) }\end{array}$ & $\begin{array}{r}0.70 \\
.70 \\
.70 \\
.70 \\
1.00 \\
1.00\end{array}$ & $\begin{array}{l}320 \\
320 \\
325 \\
325 \\
325 \\
325\end{array}$ & $\begin{array}{l}.01 \\
.025 \\
.01 \\
.025 \\
.01 \\
.025\end{array}$ & $\begin{array}{l}.679 \\
.636 \\
.685 \\
.643 \\
.652 \\
.644\end{array}$ & $\begin{array}{l}9.86 \\
9.88 \\
9.85 \\
9.87 \\
9.92 \\
9.87\end{array}$ & $\begin{array}{ll} & 9.88 \\
\text { с } & 9.875\end{array}$ \\
\hline $\begin{array}{l}\text { 2-Methoxy-5-propenylphenol_-- } \\
\text { (Isochavibetol) }\end{array}$ & $\begin{array}{l}3.00 \\
3.00\end{array}$ & $\begin{array}{l}325 \\
325\end{array}$ & $\begin{array}{l}.01 \\
.025\end{array}$ & $\begin{array}{l}.665 \\
.621\end{array}$ & $\begin{array}{l}9.89 \\
9.91\end{array}$ & 9. 90 \\
\hline $\begin{array}{l}\text { 2-Methoxy-6-propenylphenol... } \\
\text { (o-Isoeugenol) }\end{array}$ & $\begin{array}{l}0.70 \\
2.00 \\
2.00 \\
2.00 \\
2.00\end{array}$ & $\begin{array}{l}320 \\
320 \\
320 \\
325 \\
325\end{array}$ & $\begin{array}{l}.025 \\
.01 \\
.025 \\
.01 \\
.025\end{array}$ & $\begin{array}{l}.448 \\
.489 \\
.453 \\
.491 \\
.459\end{array}$ & $\begin{array}{l}\text { 10. } 21 \\
10.21 \\
10.20 \\
10.20 \\
10.20\end{array}$ & 10. 20 \\
\hline Benzoic acid & & & & & & 4. $20[12]$ \\
\hline p-Allylbenzoic acid_--- & $\begin{array}{l}\text { 2. } 00 \\
\text { 2. } 00 \\
\text { 2. } 00 \\
\text { 2. } 00\end{array}$ & $\begin{array}{l}255 \\
255 \\
260 \\
260\end{array}$ & $\begin{array}{l}\text { b. } 10 \\
\text { b. } 01939 \\
\text { b. } 10 \\
\text { b. } 01939\end{array}$ & $\begin{array}{l}.782 \\
.797 \\
.800 \\
.800\end{array}$ & $\begin{array}{l}\text { 4. } 36 \\
\text { 4. } 34 \\
\text { 4. } 32 \\
\text { 4. } 33\end{array}$ & 4. 34 \\
\hline m-Allylbenzoic acid & $\begin{array}{r}0.08 \\
.08\end{array}$ & $\begin{array}{l}240 \\
245\end{array}$ & $\left\{\begin{array}{c}.06 \mathrm{~N} \\
\mathrm{NaAc} \\
+ \\
\dot{14 \mathrm{~N}} \\
\mathrm{HAc}\end{array}\right.$ & $\begin{array}{c}\text { a. } 519 \\
.53\end{array}$ & $\begin{array}{r}\text { a } 4.33 \\
4.31\end{array}$ & a 4.32 \\
\hline
\end{tabular}

a Approximate value $( \pm 0.1 p K$ units $)$ since the optical density of the basic and/or buffered solutions changes on standing.

b Sodium acid succinate-sodium chloride buffer

c Since completion of this work these recently determined $p K$ values have come to our attention [25]. 
The presence of an allyl group usually decreases the ionization since this group furnishes electrons to the benzene ring. However, the proximity of an allyl or propenyl group ortho to the hydroxy group hinders the removal of a proton. Thus 6-allyl-2-methoxyphenol and 2-methoxy-6-propenylphenol have lower ionization constants than their respective position isomers. The small magnitude of the inductive effect of the allyl group is indicated by the very slight change in the ionization of 5-allyl-2-methoxyphenol, $p K=10.02$ (where the allyl group is meta to the hydroxyl group and exerts little if any steric and resonance effects) as compared to guaiacol, $p K=9.98$. 3-Allyl-2-methoxyphenol (3-allylguaiacol) has a slightly lower $p K$ value of 9.92 . Here again the allyl group is meta to the hydroxyl group, but the proximity of the allyl group to the methoxyl group may cause some electronic interaction. In 4-allyl2 -methoxyphenol the $p$-allyl group supplies electrons to the conjugated system and the $p K$ value of 10.19 is larger than that of 5-allyl-2-methoxyphenol $(p K=10.02)$.

Replacement of the allyl group of the position isomers of eugenol by the propenyl group lowers the respective $p K$ values by 0.12 to 0.31 . In part the acid strengthening characteristics of the propenyl group (which has a $\pi$ bond conjugated with the benzene ring) especially in the para position are due to the resonance interaction with the phenolic hydroxyl group which increases the stability of the phenoxide ion.

The apparent and thermodynamic ionization constants of the $m$ - and $p$-allyl and propenylbenzoic acids in 50 percent ethanol-water are given in table 2 . From these values the $\sigma$ values of the Hammett equation $\log \left(k / k_{0}\right)=\sigma \rho$ can be calculated. In this equation, which relates the reactivity of the side chain of an aromatic compound and the nature of the substituent, $k$ and $k_{0}$ are rate or equilibrium constants for reactions of the meta or para substituted and unsubstituted compound respectively, $\sigma$ is the substituent constant which depends on the nature and position of the substituent and $\rho$ is the reaction constant which depends on the reaction and reaction conditions.

TABLE 2.-Apparent ionization constants of allyl- and propenylbenzoic acids in 50 percent ethanol

Temperature: $25.0 \pm 0.2{ }^{\circ} \mathrm{C}$

\begin{tabular}{|c|c|c|c|}
\hline \multirow{2}{*}{ Acid } & \multicolumn{2}{|r|}{$p K \mathrm{~b}$} & \multirow{2}{*}{$\begin{array}{c}\text { Hammett } \\
\text { sigma constant }\end{array}$} \\
\hline & $\begin{array}{l}\text { Concen- } \\
\text { tration a }\end{array}$ & $\begin{array}{l}\text { Thermo- } \\
\text { dynamic }\end{array}$ & \\
\hline $\begin{array}{l}\text { Benzoic Acid } \\
\text { m-Allylbenzoic Acid } \\
\text { p-Allylbenzoic Acid } \\
\text { m-Propenylbenzoic Acid } \\
p \text {-Propenylbenzoic Acid }\end{array}$ & $\begin{array}{l}5.705 \\
5.787 \\
5.812 \\
5.765 \\
5.833\end{array}$ & $\begin{array}{l}5.694 \pm 0.012{ }^{\circ} \\
5.810 \pm 0.006 \\
5.813 \pm 0.005 \\
5.765 \pm 0.020 \\
5.844 \pm 0.004\end{array}$ & $\begin{aligned} \sigma_{m} & =-0.08 \\
\sigma_{p} & =-0.08 \\
\sigma_{m} & =-0.05 \\
\sigma_{p} & =-0.10\end{aligned}$ \\
\hline
\end{tabular}

a $p K$ (concentration) $=-\log \frac{\mathrm{C}_{\mathrm{A}}-\mathrm{C}_{\mathrm{H}^{+}}}{\mathrm{C}_{\mathrm{HA}}}$.

b Average of two or more measurements.

c Standard deviation.

The substituent constants for $m$ - and $p$-allyl and propenyl groups (table 2) were calculated from the apparent $p K$ values of the benzoic acid derivatives using the $\rho$ value of 1.522 given for the ionization of benzoic acids in 50 percent ethanol [15]. The $\sigma_{m}$ and $\sigma_{p}$ values for the allyl group are close to those reported for the $\mathrm{C}_{2} \mathrm{H}_{5}\left(\sigma_{m}=-0.04, \sigma_{p}=-0.15\right)$ and $n-\mathrm{C}_{3} \mathrm{H}_{7}\left(\sigma_{p}=-0.13\right)$ groups [16]. Differences in the sigma values for propenyl and allyl groups should be a measure of the increased resonance interaction contributed by the $\pi$ bond of the propenyl substituent which is conjugated with the benzene ring.

The $\sigma_{p}$ value of the allyl group $(-0.14)$ was the same when calculated from the thermodynamic $p K$ values of the respective substituted benzoic acids and phenols in water. A slightly lower $\sigma_{p}$ value of -0.08 was obtained from the apparent ionization constant in 50 percent ethanol. Solvation effects may account for this difference of $\sigma_{p}$ in the two solvents.

Generally, the Hammett equation is not applicable to substituents in the ortho position of the benzene ring. However, previous investigations have shown that for a few reaction series of unsymmetrically trisubstituted compounds, such as 4- and 5- substituted toluic acids [17-19], with the same substituent in the ortho position relative to the reactive group throughout the series, the reaction parameter is constant within experimental error.

Thus for the 0 -methoxyphenol (guaiacol) series the Hammett equation can be written:

$$
p K_{a}^{G}-p K_{a}^{R G}=\rho^{G} \sigma
$$

where $p K_{a}^{G}=-$ logarithm of the ionization constant of guaiacol

$p K_{a}^{R G}=-$ logarithm of the ionization constant for the substituted guaiacol

$\rho^{G}=$ reaction constant for the ionization of the guaiacol derivative.

Although there is hydrogen bonding between the hydroxyl and adjacent methoxyl group in guaiacol, the influence of the ortho methoxyl group on the ionization of the phenolic hydroxyl group is small and of importance only when the coplanarity and resonance of the molecule are concerned [20]. Thus guaiacol, 4-allyl-2-methoxyphenol, and 2-methoxy4-propenylphenol are only slightly more acidic than phenol, 4-allylphenol, and 4-propenylphenol, respectively (table 3). Furthermore, the sigma values

TABLE 3. $\quad p K$ values of substituted phenols and the corresponding guaiacols

\begin{tabular}{|c|c|c|c|c|c|}
\hline \multirow{2}{*}{ Substituent } & \multicolumn{2}{|c|}{$p K_{a}$} & \multirow{2}{*}{$p K_{a}{ }^{\text {G ua iacol }}-p K_{a} \mathrm{Phenol}$} & \multicolumn{2}{|c|}{ Sigma values } \\
\hline & Phenol & Guaiacol & & $\begin{array}{c}\text { Phenols } \\
\rho=2.29[26]\end{array}$ & $\begin{array}{c}\text { Guaiacols } \\
\rho=2.2 \mathrm{~b}\end{array}$ \\
\hline H & $10.00[8]$ a & $9.98[8]$ & -0.02 & 0.00 & 0.00 \\
\hline 4-Allyl & 10.23 & 10.19 & -.04 & -.10 & $\begin{array}{l}-.03 \\
-.10\end{array}$ \\
\hline $\begin{array}{l}\text { 5-Allyl } \\
\text { 4-Propenyl }\end{array}$ & $9.824[25]$ & $\begin{array}{r}10.02 \\
9.88\end{array}$ & +.06 & $\begin{array}{r}+.08 \\
\end{array}$ & $\begin{array}{l}-.02 \\
+\quad 05\end{array}$ \\
\hline 5-Propenyl & -........ & 9.90 & & & +.04 \\
\hline
\end{tabular}

a Brackets indicate literature reference.

b $\rho$ calculated from the $p K$ values of phenol, guaiacol, 4-hydroxymethyl-[20], 4-allyl- and 4-propenyl phenol and guaiacol. 
for the 4-allyl- and 4-propenyl group when calculated from the $p K$ values of the respective phenol and guaiacol derivative and unsubstituted compound agree within experimental error.

The above equation does not hold for 3-allyl-2methoxyphenol since the allyl group in the 3-position will affect the interaction between the methoxyl and the phenol group. The principle of additivity of substituent effects for obtaining the change of the free energies of ionization of 2,3-disubstituted benzoic acids often leads to serious discrepancies between the calculated and observed values [21]. Similar discrepancies should occur for 2,3-disubstituted phenols and even larger differences would be expected for 2,6-disubstituted derivatives (6-allyl2-methoxyphenol). The propenyl group with a $\pi$ bond conjugated with the double bonds of the aromatic nucleus withdraws electrons from the ring: In $p$-propenylbenzoic acid the $-R$ resonance effect of the propenyl group is transmitted to the para carbon atom of the ring by conjugation, but must be relayed to the acidic $-\mathrm{OH}$ group by induction. On the other hand the 4-propenyl group is in direct resonance interaction with phenolic $\mathrm{OH}$.
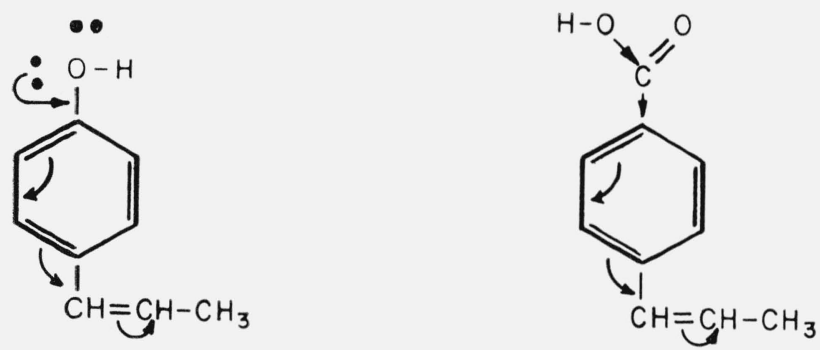

Departures from the Hammett equation have generally been observed for reaction equilibria involving derivatives of anilines and phenols having $-R$ groups para to the reaction center. For such reactions a second set of substituent constants somewhat greater than the normal $\sigma$ values and denoted by $\sigma_{p}^{c}$ (the superscript $c$ indicating direct conjugation) has been suggested [22]. This agreement of the sigma values derived from $p$-propenylbenzoic acid and from 4-propenyl-2-methoxyphenol should not be expected.

\subsection{Reaction of the Eugenol Isomers With Zinc Oxide}

The four eugenol isomers were mixed with zinc oxide, and zinc oxide containing 1 percent zinc acetate to determine their relative reactivities in the chelating reaction with zinc. Final setting times were determined at $37{ }^{\circ} \mathrm{C}$ and 100 percent relative humidity according to American Dental Association Specification No. 9 [23]. Results are given in table 4.

Slurries containing 6-allyl-2-methoxyphenol do not harden and those containing 3-allyl-2-methoxyphenol set only in the presence of zinc acetate.
5-Allyl-2-methoxyphenol mixes, especially those containing zinc acetate harden faster than eugenol mixes. The greatly reduced reactivity of the vicinally substituted isomers as compared to the unsymmetrically substituted ones shows that the chelation reaction is greatly influenced by steric hindrance of the bulky neighboring allyl groups. Studies to determine if substitution of metals with smaller atomic radii than zinc will reduce this steric effect would be of interest.

TABLE 4. Reactivities of eugenol isomers with $\mathrm{ZnO}$

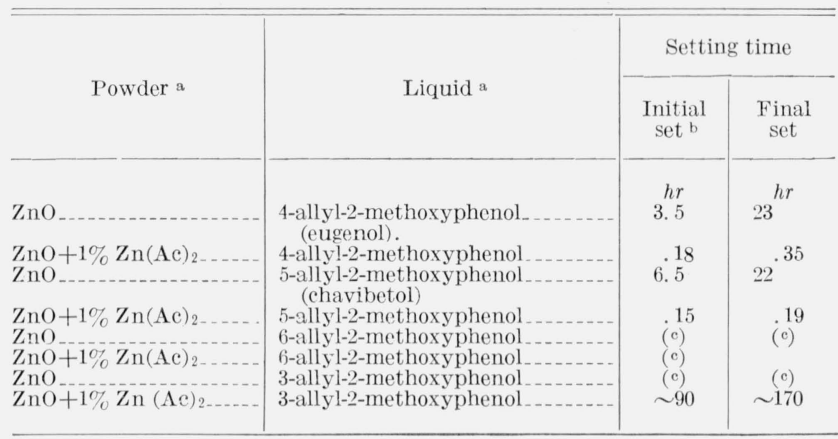

a Powder-liquid ratio: $1.3 \mathrm{~g}$ powder per $0.4 \mathrm{ml}$ liquid.

b Initial setting time in hours is the time elapsed from starting the mix to the time when the point of a penetrating instrument such as the point of a Gilmore needle makes only a slight but visible indentation after placing the needle on the material for 5 see.

Did not harden within 10 days.

Besides steric effects of the substituent groups, the chelation reaction is also dependent to a lesser degree on the ionization constants of the isomers. Thus, 4 -allyl-2-methoxyphenol (eugenol) $(p K=10.19)$ is somewhat less reactive than 5-allyl-2-methoxyphenol (chavibetol) $(p K=10.02)$.

For the reaction of the nucleophilic chelating agents (eugenol or chavibetol) with zinc oxide the reaction constant $\rho$ is likely to be positive. The increased rate of setting of 5-allyl-2-methoxyphenol compared to 4-allyl-2-methoxyphenol would thus be expected since in water the sigma value of the meta allyl- is slightly larger than that of the para allyl group [24]. Results of this study would indicate that synthesis of new chelate cements should be directed towards derivatives with unsymmetrically substituted groups (1,2,4- and 1,2,5- substituted benzene derivatives).

The authors thank R. A. Robinson for valuable suggestions and R. W. Morris for assisting in some of the experimental work.

\section{References}

[1] Copeland, H. I., G. M. Brauer, W. T. Sweeney, and A. F. Forziati, J. Res. NBS 55, 133 (1955).

[2] Brauer, G. M., R. W. Morris, and W. B. Howe, J. Res. NBS 6\%A, 265 (1963).

[3] Schöpf, C., E. Brass, E. Jacobi, W. Mocnik, L. Neuroth, and W. Salzer, Ann. 544, 30 (1940).

[4] Pal'gi, M., J. Gen. Chem. U.S.S.R. 28, 2278 (1958).

[5] Quelet, R., Bull. Soc. Chim. France [4] 45, 75 (1929).

[6] Quelet, R., Ibid [4], 45, 255 (1929). 
[7] Robinson, R. A. and A. I. Biggs, Trans. Faraday Soc. 51, 901 (1955).

[8] Biggs, A. I., Trans. Faraday Soc. 52, 35 (1956).

[9] Bates, R. G., G. D. Pinching, and E. R. Smith, J. Res. NBS 45, 418 (1950).

[10] Bates, R. G., and R. Gary, J. Res. NBS 65A, 495 (1961).

[11] Britton, H. T. S., Hydrogen Ions, 4th ed., D. Van Nostrand Co., Princeton, N.J., Vol. 1, p. 357 (1956).

[12] Robinson, R. A., and R. H. Stokes, Electrolyte Solutions, 2d ed., Academic Press, New York, N.Y. (1959).

[13] Bates, R. G., M. Paabo, and R. A. Robinson, J. Phys. Chem. 6\%, 1833 (1963).

[14] Åkerlöf, G., J. Am. Chem. Soc. 54, 4125 (1932).

[15] MeDaniel, D. H., and H. C. Brown, J. Org. Chem. 23, 420 (1958).

[16] Jaffe, H. H., Chem. Rev. 53, 191 (1953).

[17] Roberts, J. D., and J. A. Yancy, J. Am. Chem. Soc. 73, 1011 (1951).

[18] Peltier, D., Bull. Soc. Sci. Bretagne 31, 7 (1956).
[19] Peltier, D., Bull. Soc. Chim. France 1958, 994.

[20] Juslén, C. and J. J. Lindberg, Finska Kemistsamf. Medd. 68, 53 (1959).

[21] Shorter, J. and F. J. Stubbs, J. Chem. Soc. 19491180.

[22] Gould, E. S., Mechanism and Structure in Organic Chemistry, H. Holt and Co., New York (1959), Ch. VII, pp. 199-243.

[23] American Dental Association Specification No. 9 for Dental Silicate Cements. Guide to Dental Materials 1964-1965, American Dental Association, Chicago, Ill. 60611 (1964), p. 107.

[24] Brauer, G. M., H. Argentar, and G. Durany, (unpublished results).

[25] Lindberg, J. J., C. G. Nordström and R. Lauren, Suomen Kem. 35B, $182(1962)$

[26] Biggs, A. I. and R. A. Robinson, J. Chem. Soc. 1961, 388.

Paper $68 \mathrm{~A}-309$ 